\title{
Stella Strzemecka
}

INSTYTUT SOCJOLOGII

UNIWERSYTET JAGIELLOŃSKI KRAKÓW

E-MAIL: STELLA.STRZEMECKA@UJ.EDU.PL

\section{INTERNAUCI O „MATCE-ZABÓJCZYNI”. PRZYCZYNEK DO ANALIZY SOCJOLOGICZNEJ}

\section{Wprowadzenie}

Czyn dzieciobójstwa lub zabójstwa dziecka pociągający za sobą złamanie norm moralnych, religijnych oraz prawnych nie jest w XXI wieku zjawiskiem nowym. Świadczą o tym liczne dokumenty nie tylko z czasów starożytnych, ale również z wieków późniejszych [Markowska, Neugebauer 1989: 77, 79, 83; por. Geremek 1989]. Jednak obecnie zabójstwo dziecka jest w naszej kulturze zbrodnią szczególnie piętnowaną. Śmierć dziecka, zwłaszcza gdy sprawczynią jest matka, to wydarzenie, które w powszechnym poczuciu sprawiedliwości nie powinno mieć miejsca. Absorbuje media, a wraz z nimi opinię publiczną [Markowski 2010: 114], upatrującą w aktach dzieciobójstw i zabójstw dzieci zagrożenia dla stabilności ładu moralnego i degenerację więzi rodzinnych. Wpływ mediów na odbiorców jest rozmaity, gdyż różni są sami odbiorcy. Różnią się poziomem wiedzy, doświadczeniem życiowym, opiniami najbliższego otoczenia, indywidualnymi autorytetami, kontaktami z mediami. Nie ulega wątpliwości, że obecność konkretnej tematyki w mediach powoduje, iż jest ona uznawana za istotną. Prowokuje bowiem do wymiany opinii [zob. Pokorna-Ignatowicz 2012]. Postęp technologiczny spowodował, że wszelkie formy działania społecznego, gospodarczego i politycznego są coraz częściej poddawane publicznej ocenie, a, jak wiadomo, moralność podlega ewolucji wraz ze zmianą społeczną [Kostro 2001].

Medialne doniesienia o drastycznych przypadkach mogą niesłusznie wskazywać na narastanie skali zjawiska [Kühn 2010: 20]. W rzeczywistości statystyki policyjne mówią nawet o spadku liczby zabójstw małoletnich na przestrzeni lat [Policja 2012]. Pomimo dostępnych danych niewiele wiadomo o skali problemu zabójstw dzieci. Liczne badania wskazują, że statystyki zabójstw dzieci są 
w Polsce niedoszacowanie ${ }^{1}$. Co więcej, w statystykach nie występuje rozróżnienie na płeć sprawcy, dlatego nie można jednoznacznie rozstrzygnąć, czy zabójstw małoletnich dopuszczają się głównie mężczyźni czy kobiety².

\section{Kontekst badań}

Od 2012 roku przypadki dzieciobójstw i zabójstw dzieci są tematami szczególnie ważnymi, ze zwiększoną częstotliwością podejmowanymi w mediach. Można tu wskazać na szczególny czas społeczny, kiedy to na jaw wyszło rzekome zaginięcie, które później okazało się zabójstwem kilkumiesięcznej Magdy z Sosnowca. Temat dziewczynki wywołał masowe zainteresowanie i społeczne emocje, które nadal są obecne w polskim społeczeństwie. Ze wstępnej analizy zawartości internetowych artykułów i obserwacji forów internetowych wynika, że opinia publiczna skupiając uwagę na konkretnym śledzonym przypadku nawiązuje w osądach do najbardziej medialnych spraw dzieciobójstw/zabójstw z lat ubiegłych. Problematyka rodziców, którzy zabijają (szczególnie matek) absorbuje nie tylko rzeszę dziennikarzy, publicystów oraz ekspertów, ale także czytelników prasy papierowej i internetowej. Świadczą o tym odnotowane zyski ze sprzedaży prasy i rekordowe poziomy oglądalności programów telewizyjnych podnoszących temat konkretnych dzieciobójstw/zabójstw dzieci [Nielsen 2012], a także aktywność internautów na forach dyskusyjnych.

\section{Założenia metodologiczne}

Analiza obejmowała anonimowe komentarze użytkowników Internetu zamieszczone pod artykułami dwóch najstarszych i najpopularniejszych polskich portali Wp.pl („Wirtualna Polska”) i Onet.pl („Onet”). Zbadano komentarze dotyczące trzech najbardziej medialnych przypadków dzieciobójstw i zabójstw małoletnich na przestrzeni ostatniej dekady (w okresie 2003-2013). W trakcie

1 Od 2007 roku ofiarami zabójców (tj. z art. 148 k.k.) pada średnio każdego roku około 20-30 małoletnich. Wszczynanych jest także średnio około 30 postępowań w kierunku dzieciobójstwa (tj. z art. 149 k.k.), jednak kończą się stwierdzeniem zaledwie od kilku do kilkunastu przestępstw tej kwalifikacji rocznie [Kühn 2010: 15-17].

2 Wyniki badań zagranicznych z 2007 roku wskazują jednoznacznie, że sprawcami zabójstw dzieci są głównie mężczyźni - ojcowie, ojczymowie lub partnerzy matki [Włodarczyk 2012: 107]. 
badania społeczności internetowych zostały wykorzystane metody badań netnograficznych [Kozinets 2012: 13-16].

Celem artykułu była próba stworzenia typologii internautów osądzających matkę, która zabiła swoje dziecko. Typologia jest zabiegiem systematyzującym, precyzującym, polegającym na grupowaniu, porządkowaniu i podziale zjawisk według ustalonych typów oraz opisie tych typów [Słownik 2013] nierzadko stosowanym w psychologii i socjologii. Typologia - w odróżnieniu od klasyfikacji - nie jest wyczerpującym czy też rozłącznym podziałem określonego zbioru. Niektóre elementy mogą wykazywać cechy mieszane i nie można ich jednoznacznie przypisać do danego typu.

W niniejszym artykule podjęto również próbę weryfikacji szeroko rozpowszechnianych, na przestrzeni ostatnich lat, spostrzeżeń manifestujących się w stwierdzeniu, że kultura popularna dostarcza licznych przykładów na to, iż matki poddaje się publicznej ocenie, krytykuje i stygmatyzuje w znacznie większym stopniu niż ojców, ugruntowując tym samym typowe stereotypy płci [Goulding, Spacey 2003: 35; Hryciuk, Korolczuk 2012: 7].

\section{Uzasadnienie przyjętych założeń}

Wyniki badań wstępnych - analizy zawartości internetowych artykułów i obserwacje forów internetowych - wskazują na słuszność przyjętych założeń. Mimo iż wskazuje się na fakt, że znika postać matki-złej, i zastępuje ją matka-chora, co jest zazwyczaj jednoznaczne wiązane $\mathrm{z}$ matką w depresji [zob. Sikorska 2009: 30, 2012], to wciąż w społecznym przeświadczeniu funkcjonuje mocno zakorzeniony ideał matki okazującej wobec dzieci uczucia wyłącznie pozytywne [Budrowska 2000: 37, 382].

Można wstępnie stwierdzić, że opinia publiczna, skupiając uwagę na konkretnym śledzonym przypadku nawiązuje w swych artykułach czy komentarzach do najbardziej medialnych spraw dzieciobójstw i zabójstw z lat ubiegłych. Dlatego też przyjęto taki cezus czasowy. Należy wyraźnie podkreślić, iż analiza obejmująca trzy przypadki zabójstw dzieci na podstawie dwóch źródeł (Wp.pl i Onet.pl) nie rości sobie prawa do generalizacji. Ma jedynie pełnić rolę przyczynku do dalszych badań. 


\section{Charakterystyka wybranych przypadków}

\section{Czyn Jolanty K. i Andrzeja K.}

Matce postawiono zarzut: „dokonania w latach 1992-1998 zabójstw dzieci tuż po ich urodzeniu i po stwierdzeniu, że są żywe. Ojcu dzieci postawiono zarzut nakłaniania żony do zabójstwa poprzez groźby i bicie" [Heitzman, Ruzikowska, Tarczyńska, Waszkiewicz, Pilszyk 2013: 547].

\section{Czyn Beaty Ch. i partnera}

O zabójstwo podejrzana była matka dziecka Beata Ch., a na jej konkubencie ciążył zarzut nieudzielenia pomocy chłopcu. Zwłoki dziecka znaleziono w marcu 2010 roku w stawie na obrzeżach Cieszyna. Media poświęciły tej sprawie wiele miejsca zarówno w 2010 roku, kiedy chłopiec został znaleziony, jak i w 2012 roku, kiedy ustalono jego tożsamość.

\section{Czyn Katarzyny W.}

Sprawa została nagłośniona w styczniu 2012 roku, kiedy zgłoszono zaginięcie córki Katarzyny W. i Bartłomieja W. Później wyszło na jaw, że dziewczynka została pozbawiona życia przez matkę. Od tego czasu "historia Mamy Madzi” stała się integralną częścią polskiej kultury masowej. „Mama Madzi” stała się żartem i obiektem kpin, na niespotykaną dotąd skalę.

\section{Typologia internautów osądzających „matkę-zabójczynię”}

\section{Ujęcie ilościowe}

Pod trzema analizowanymi przypadkami zidentyfikowano 36758 komenta$\mathrm{rzy}^{3}$. Ze względu na bogatą ilość potencjalnego materiału badawczego, poddano analizie 300 celowo wybranych komentarzy (po 100 komentarzy z każdego przypadku). Na podstawie wypowiedzi internautów podzielono komentujących na dwie główne grupy: 1. Internauci odnoszący się bezpośrednio do osoby sprawczyni, 2. Internauci odnoszący się pośrednio do osoby sprawczyni (rysunek 1).

3 Jolanta K. i Andrzej K.: 557 komentarzy od 2003 roku, Beata Ch. i partner: 12158 komentarzy od 2010 roku, Katarzyna W.: 24043 komentarzy od lipca 2012 roku (ze względu na nagromadzenie potencjalnego materiału empirycznego na temat Katarzyny W., analizie zostały poddane komentarze zamieszczone po ujawnieniu informacji, że matka jest sprawczynią zbrodni, czyli od 12 lipca 2012 roku). 
Rysunek 1. Internauci komentujący „matkę-zabójczynię” [\%]
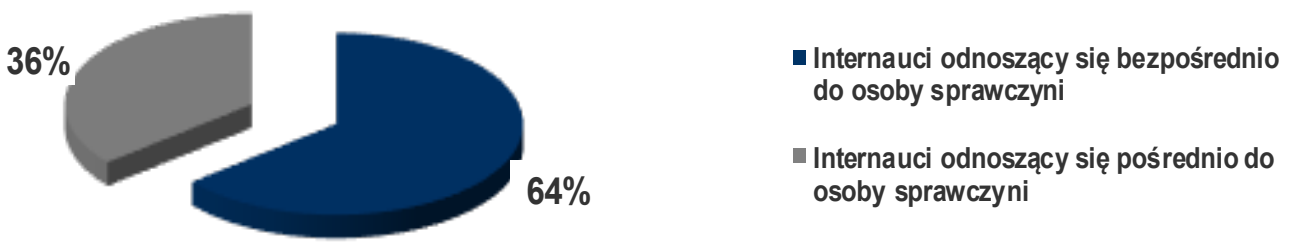

Źródło: opracowanie własne na podstawie zebranych danych.

W dalszej kolejności (w ramach danej grupy głównej) wyodrębniono typy internautów, których udział w dyskusjach przedstawia się następująco:

I. Internauci odnoszący się bezpośrednio do osoby sprawczyni (192 komentarze - 64\%)

1. Nawołujący do egzekucji (74\% - 142 komentarze)

2. Oskarżyciele opowiadający się za dożywociem (11\% - 21 komentarzy)

3. Wykpiwacze (10\% - 20 komentarzy)

4. Wierzący w nawrócenie ( $5 \%-9$ komentarzy)

II. Internauci odnoszący się pośrednio do osoby sprawczyni (108 komentarzy - 36\%)

1. Upatrujący winy w systemie państwowym $(62 \%-67$ komentarzy)

2. Upatrujący winy w członkach społeczeństwa $(21 \%-23$ komentarze)

3. Upatrujący winy w mediach $(13 \%-14$ komentarzy)

4. Wskazujący na degenerację więzi rodzinnych ( $4 \%-4$ komentarze)

\section{Ujęcie jakościowe}

Cytaty $\mathrm{z}$ wypowiedzi internautów przytacza się $\mathrm{w}$ oryginalnej pisowni. W celu zapewnienia większej anonimowości zrezygnowano $\mathrm{z}$ ujawniania nicków ${ }^{4}$ komentujących. W nawiasie kwadratowym podano informację o przypadku, do którego odnosi się komentujący internauta oraz źródło, z którego zaczerpnięto cytat.

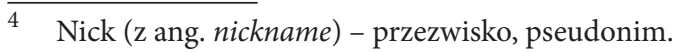


I. Internauci odnoszący się bezpośrednio do osoby sprawczyni

W ramach pierwszej grupy internautów wyodrębniono cztery typy: 1 . Nawołujący do egzekucji, 2. Oskarżyciele opowiadający się za dożywociem, 3. Wykpiwacze, 4. Wierzący w nawrócenie.

1. Nawołujący do egzekucji nie stronią od wulgarnych określeń. W brutalny, werbalny sposób odnoszą się do osoby sprawczyni. Twierdzą, że za czyn, którego dopuściła się matka dziecka kara więzienia, „to za mało”. Wyrażają pogląd, że dla osób pozbawiających życia niewinne istoty takie jak dzieci, kary powinny być o wiele surowsze, na przykład kara śmierci: „potwór!, kobieto życzę Ci byś zdechła, konała w takich samych męczarniach jak twój biedy synek, nie należy Ci się nawet przydomek matka. Ludzie powinni połamać Ci ręce i tak długo kopać po brzuchu aż tak samo jak dziecku pęknie ci jelito, powinnaś umrzeć w męczarniach gdy gówno wydostanie się z jelit” [o sprawie Beaty Ch. na Wp.pl].

2. Oskarżyciele opowiadający się za dożywociem nie są w stanie zrozumieć jak człowiek mógł dopuścić się takiego czynu. Twierdzą, że za czyn, którego dopuściła matka dziecka odpowiednia będzie dożywotnia kara więzienia:

„Psychopatka i tyle. Powinna dostać dożywocie. Żal tylko pieniędzy na jej utrzymanie w więzieniu. Powinna ciężko pracować na swoje życie za kratkami. Nic nie usprawiedliwia zabójstwa dzieci" [o sprawie Jolanty K. na Onet.pl].

3. Wykpiwacze wyrażają pogardę wobec matki-sprawczyni:

„Nowa Polska żywność regionalna... ...,,noworodki peklowane w kapuście", polecana szczególnie na biskupie stoły...!” [o sprawie Jolanty K. na Wp.pl].

4. Wierzący w nawrócenie są przeciwni głosom, że matka powinna zostać dożywotnio pozbawiona prawa do posiadania dzieci (na przykład poprzez zabieg medyczny). Wyróżniają się werbalną empatią. Nie potępiają kategorycznie czynu przestępczego. Wierzą w zmianę i „nawrócenie" sprawczyni:

Nigdy nie należy nikogo z góry skreślać. Każdy może się zawsze nawrócić i pokochać swoje dzieci. Jest wiele przypadków, że matki porzucały swoje dzieci, a potem gdy te dorosły chciały wrócić do nich. Są nieraz błędy młodości. Nie wolno na zawsze pozbawiać kogoś możliwości macierzyństwa [o sprawie Beaty Ch. na Onet.pl]. 


\section{Internauci odnoszący się pośrednio do osoby sprawczyni}

W ramach drugiej grupy internautów wyodrębniono cztery typy internautów: 1 . Upatrujący winy w systemie państwowym, 2. Upatrujący winy w członkach społeczeństwa, 3. Upatrujący winy w mediach, 4. Wskazujący na degenerację więzi rodzinnych.

1. Upatrujący winy w systemie państwowym za zaistniałą sytuację obwiniają przede wszystkim rząd i jego działania, a konkretniej bak działań prewencyjnych. Uważają, że polskie sądownictwo jest „ułomne” i nie chroni interesów prawych obywateli. Uważają, że odpowiednie instytucje powinny „lepiej” realizować swoje funkcje, roztaczać opiekę nad obywatelami, szczególnie tymi najmłodszymi:

„polska to jest kraj gdzie mozna mordowac dzieci i do wiezienia nie idziesz!!!!!!!!podziekowac TUSKOWI [Premierowi - przyp. aut.] za to co sie dzieje w zalosnej polsce" [o sprawie Beaty Ch. na Wp.pl].

2. Upatrujący winy w członkach społeczeństwa są zdania, że tragedii można było uniknąć przy większym zaangażowaniu sąsiadów lub bliskiej rodziny (cytat 1):

Gdy Katarzyna W. zostawiła dziecko i wyszła z domu to już wtedy trzeba było zacząć ją leczyć i szukać pomocy dla niej u psychologa lub psychiatry, a nie teraz „wybielać” mamusię, że to niby tak cudownie scaliła rodzinkę. Żałosne jest to, że Bartek W. nie rozumie na czym polega rola męża i ojca. Co zrobił gdy jego żona zachowywała się źle wobec dziecka? W jaki sposób pomagał jej pokonać stres poporodowy i depresję poporodową? (...), [o sprawie Katarzyny W. na Onet.pl].

Upatrujący winy w członkach społeczeństwa czasami wykorzystują dyskusję na temat śmierci dziecka do opowiedzenia swojej historii. Chcą, aby ktoś zwrócił uwagę na to, że innym ludziom w społeczeństwie również przydarzają się tragedie (cytat 2):

Moja mama bardzo kochała Ojca i była o niego zazdrosna. Wszystkie swoje porażki wyładowywała na nas. Byliśmy nawet bici za to;;;ze zjadliśmy kiełbasę schowaną w szafie dla Taty.!!!Zawsze baliśmy się wiszącego nad nami BATA!!!I ten lęk idzie ze mną ;;przeszkadzając mi w życiu...Nie mam odwagi,,,,swojego zdania... prawa do samej siebie. Ja myślałam że;;;tak trzeba wychowywać dzieci i też biłam swoją Cureczkę..!!!Teraz stale ją za to przepraszam,,,,ale z Wielki Bagażem poczucia Wstydu muszę żyć do śmierci. (...) Też mam dzieci i robię dla nich dużo!!!ale cieszę sie z tego i nie czekam na pokłony i nie wymawiam im tego,,,bo to muj OBOWIĄZEK” [o sprawie Beaty Ch. na Onet.pl]. 
3. Upatrujący winy w mediach wskazują na „znudzenie” tematem oraz niechęć do „szukania przez media sensacji na siłę”:

„Zastanawiam się jak długo jeszcze będziecie ten temat wałkowali. Tysiące dzieci umiera na przykład przez złą opiekę medyczną, a oni swoje. Co ten chłopczyk, Szymon itd. itd. Poświęcacie tyle miejsca dla nieżyjącego, że się wymiotować chce. I te kretyńskie zdjęcia, które zamiast współczucia wywołują niechęć" [o sprawie Beaty Ch. na Onet.pl].

4. Wskazujący na degenerację więzi rodzinnych uważają, że wszystkiemu winien jest charakter związku, w jakim przebywają partnerzy i wartości, jakimi się kierują. Małżeństwo traktują jak „odpowiedzialną instytucję”, "dojrzałą" do wychowywania dzieci. Wyrażają więc wątpliwości czy ludzie w tak zwanym wolnym związku mogą - w sposób odpowiedzialny - zająć się potomstwem. Wskazują również na „zanik tradycyjnego modelu” rodziny w „dzisiejszych czasach”.

To są właśnie tak zwane wolne związki.Brak odpowiedzialności za siebie nawzajem jak również za dzieci.Dotąa jesteśmy razem dopóki jest fajnie.Jeżeli komuś w takim luźnym związku powinie się noga to druga strona wyrzuca go na śmietnik. To samo tyczy się sytuacji dzieci w takich wolnych związkach.Niedojrzałość współczesnych ludzi.Uciekanie od odpowiedzialności za własne czyny. [o sprawie Beaty Ch. na Onet.pl].

\section{Próba syntezy i perspektywy dalszych badań}

Opierając się na rezultatach przeprowadzonych badań można wstępnie przyjąć, że zarówno ilość, jak i treść komentarzy pod internetowymi artykułami na temat „matek-zabójczyń” stanowi element społecznego odwetu. Komentarze internatów najczęściej odnosiły się do matki, bardzo rzadko do ojca/partnera. Zdecydowanie częściej internauci o „matkach-zabójczyniach” pisali jako o głównych winowajczyniach. Wśród wszystkich (poddanych analizie) wypowiedzi, dominują te o wydźwięku negatywnym, nawołujące do egzekucji. Anonimowość w Internecie pozwala bowiem na większą otwartość emocjonalną i swobodę w zachowaniu. John Suler szczegółowo opisał tzw. efekt rozhamowania (disinhibition effect), dający się zaobserwować u internautów [Suler 2004]. Pisze on, że w sieci niektórzy mogą stać się niezwykle nieuprzejmi, czy źli. Badacz określa to zjawisko jako rozhamowanie toksyczne (toxic disinhibition). Jednostki reagując emocjonalnie na wymianę treści podejmują w Internecie 
rozmaite działania restytuujące sprawiedliwość, mające na celu zredukowanie poczucia niesprawiedliwości [Lerner 1980; Lawler 2009: 179].

Z corocznych raportów Amnesty International wynika, że liczba wykonywanych kar śmierci nie maleje. Takie wyroki jak amputacje, oślepianie, krzesło elektryczne, ukrzyżowanie, powieszenie czy ukamienowanie są wciąż wykonywane zgodnie z prawem w około 21 krajach [Amnesty 2013]. Patrząc przez pryzmat kultury zachodniej, można wysunąć wniosek, że tego rodzaju publiczne egzekucje, to „barbarzyństwo”. Jeśli jednak przeniesie się obserwację do sieci (zawartość komentarzy internautów, na przykład pod medialnymi doniesieniami o popełnionej zbrodni) to można odnieść wrażenie, że chęć wymierzania sprawiedliwości przez brutalne kary fizyczne jest powszechna. Wraz ze zniesieniem kary śmierci przez większość krajów i popularyzacją dyskursu „humanitarności” owa chęć znalazła ujście nie tylko w możliwości udostępniania i/lub oglądania materiałów w Internecie. Również w możliwości komentowania rozmaitych czynów przestępczych, umożliwiając tym samym dokonywanie samosądów on-line.

Wszystko wskazuje na to, iż sprawczynie poddaje się publicznej ocenie, krytykuje i stygmatyzuje w znacznie większym stopniu niż sprawców, ugruntowując tym samym typowe stereotypy płci [Goulding, Spacey 2003: 35; Hryciuk, Korolczuk 2012: 7]. Jednak charakter wypowiedzi internatów odnoszących się do „matki-zabójczyni” wymaga dalszych, szczegółowych badań. Z uwagi na to, zaprezentowana analiza nie rości sobie prawa do generalizacji. Stanowi jedynie inspirację i może wyznaczać perspektywy dalszych badań.

\section{Biblografia}

\section{Książi i artykuty}

Budrowska B. (2000), Macierzyństwo jako punkt zwrotny w życiu kobiety, Wrocław Geremek B. (1989), Litość i szubienica. Dzieje nędzy i miłosierdzia, Warszawa

Goulding A., Spacey R. (2003), Women and the Information Society: barriers and participation, "IFLA Journal" 29(1): 33-40

Heitzman J., Ruzikowska A., Tarczyńska K., Waszkiewicz E, Pilszyk A. (2013), Dzieciobójstwo czy zabójstwo? Studium przypadku 5-krotnego zabójstwa własnych dzieci-poszukiwanie psychopatologii, „Psychiatria Polska” t. XLVII, nr 3: 541-558

Hryciuk R. E., Korolczuk E. (2012), Wstęp. Pożegnanie z Matka Polką?, [w:] R. E. Hryciuk, E. Korolczuk (red.), Pożegnanie z Matką Polką? Dyskursy, praktyki i reprezentacje macierzyństwa we współczesnej Polsce, Warszawa

Kostro C. (2001), Funkcjonalna teoria moralności Niklasa Luhmanna, Kraków 
Kozinets R. V. (2012), Netnografia. Badania etnograficzne online, Warszawa

Kühn G. (2010), Przypadki krzywdzenia dzieci ze skutkiem śmiertelnym, „Dziecko Krzywdzone" nr 3(32): 7-23

Lawler E. J. (2009), Teoria afektu w wymianie społecznej, [w:] A. Manterys, J. Mucha (red.), Nowe perspektywy teorii socjologicznej, Kraków: 155-184

Lerner M. J. (1980), The belief in a just world. A fundamental delusion, New York, Plenum Press

Makowski R. (2010), Media wobec śmiertelnych przypadków krzywdzenia dzieci, „Dziecko Krzywdzone" nr 3(32): 104-115

Markowska D., Neugebauer K. (1989), Przerywanie ciąży, [w:] M. Kozakiewicz (red.), Pro i contra $w$ planowaniu rodziny $w$ wychowaniu seksualnym, Warszawa: 73-93

Pokorna-Ignatowicz K. (red.), (2012), Medialny obraz rodziny i płci, Kraków

Sikorska M. (2009), Matka "chora” zamiast "złej” - o nowych wzorach macierzyństwa, [w:] M. Sikorska (red.), Być rodzicem we współczesnej Polsce: nowe wzory w konfrontacji z rzeczywistościa, Warszawa: 13-33

Sikorska M. (red.), (2012), Ciemna strona macierzyństwa. O niepokojach współczesnych matek, Warszawa

Suler J. (2004), The Online Disinhibition Effect, "CyberPsychology and Behavior" nr 7: 321-326

Włodarczyk J. (2012), Śmierć dzieci jako konsekwencja krzywdzenia i/lub zaniedbania, „Dziecko Krzywdzone" nr 2(39): 104-115

\section{Źródła internetowe}

Amnesty International (2013), Death Sentences and Executions 2012, http://amnesty.org.pl/uploads/media/Raport_ENG.pdf [21.07.2013]

Nielsen Audience Measurement (2012), Raport tygodniowy: oglądalność stacji telewizyjnych. Dane $z$ okresu 30.01.2012-5.02.2012, http://www.agbnielsen.pl/2012-02-05,1701.html [28.12.2012]

Policja (2012), Liczba ofiar przestępstw w 2011 roku, http://statystyka.policja.pl/portal/ st/840/74956/Liczba_ofiar_przestepstw_w_2011_roku.html?search=8048 [21.11.2012]

Słownik języka polskiego, Hasło: Typologia, http://sjp.pwn.pl/slownik/2579028/typologia [21.02.2013]

\section{Materiał empiryczny}

Onet.pl [21.08.2003-31.05.2013]

Wp.pl [21.08.2003-31.05.2013] 


\section{SUMmaRY}

\section{Internet Users about a "Killer Mother". The Contribution to the Sociological Analysis}

The article focuses on the analysis of social reactions that manifest themselves in the form of comments of Internet users regarding mothers who killed their children. The aim of the study was an attempt to create a typology of Internet users judging a "killer mother". The analysis includes anonymous Internet users who posted comments under the articles of two portals: Wp.pl ("Wirtualna Polska") and Onet.pl ("Onet"). Comments on three selected cases of murders of minors in Poland over the decade (2003-2013) were submitted.

\section{Keywords:}

murder of a minor, mother, Internet users, comments, netnography 